\title{
Gibberellic Acid-induced Flowering of Syngonium podophyllum Schott 'White Butterfly'
}

\author{
R.J. Henny and D.J. Norman \\ University of Florida, Institute of Food and Agricultural Science, Central \\ Florida Research and Education Center, 2807 Binion Road, Apopka, FL 32703

\section{M.E. Kane} \\ Department of Environmental Horticulture, P.O. Box 110670, University of \\ Florida, Gainesville, FL 32611
}

Additional index words. Nephthytis, foliage plant, breeding, growth regulators

Abstract. Syngonium 'White Butterfly', growing in 1.6-L pots and treated in August with a single $\mathrm{GA}_{3}$ spray at 250 to $2000 \mathrm{mg} \cdot \mathrm{L}^{-1}$, flowered within 86 days. Mean flower number increased with $\mathrm{GA}_{3}$ concentration. Flowers were normal in appearance and were fertile. Chemical name used: gibberellic acid $\left(\mathbf{G A}_{3}\right)$.

Members of the family Araceae, commonly called aroids, are one of the most important group of ornamental tropical foliage plants. Five aroid genera, including Aglaonema, Dieffenbachia, Spathiphyllum, Epipremnum, and Syngonium, were responsible for $19 \%$ of the annual wholesale volume in Florida in 1993 (Sheehan, 1994), and interest continues in developing new cultivars. Consumers prefer plants with novel foliage that perform well in interior environments. Growers seek plants with good growth rates, branching, and an attractive growth habit, in addition to insect and disease resistance.

Unpredictable flowering patterns of aroids greatly hindered attempts at breeding until Aglaonema (Henny, 1983), Dieffenbachia (Henny, 1980), and Spathiphyllum (Henny, 1981) were induced to flower with a single foliar spray of gibberellic acid $\left(\mathrm{GA}_{3}\right)$. Although some $\mathrm{GA}_{3}$-induced flowers may be distorted and small, fertility is not affected. The ability to control flowering of these aroids has permitted breeders to develop new Aglaonema and Dieffenbachia cultivars, and allowed commercial production of blooming Spathiphyllum on predictable schedules throughout the year.

The aroid genus Syngonium consists of $\approx 20$ species native to tropical Central and South America. Because of the shape of juvenile leaves Syngonium are commonly referred to as nephthytis, or as arrowhead vine. A single species, S. podophyllum Schott., is the origin of most commercially grown nephthytis. New cultivars have been introduced directly from the wild or selected from mutants ob-

Received for publication 18 May 1998. Accepted for publication 3 Nov. 1998. Florida Agricultural Experiment Station Journal Series No. R-06404. The cost of publishing this paper was defrayed in part by the payment of page charges. Under postal regulations, this paper therefore must be hereby marked advertisement solely to indicate this fact. served during production. In the past 10 years, tissue culture has become the primary method of propagation as well as the primary source of mutations. In a recent report, 28 different Syngonium cultivars propagated in vitro and available in Florida were classified morpho- logically (Henley and Robinson, 1993). Extensive differences in several morphological characteristics were observed, including plant height and width, leaf length, width and color, and number of basal shoots (Henley and Robinson, 1993).

The diversity of important ornamental traits makes Syngonium a desirable genus for improvement by breeding. Hybridization could also be used to introduce genes into $S$. podophyllum from other species to increase the genetic base. Consequently, ability to control flowering of Syngonium is important. However, under low light levels in commercial greenhouse and interiorscapes, Syngonium does not flower.

\section{Materials and Methods}

To test the effect of $\mathrm{GA}_{3}$ on flowering of Syngonium, an experiment was initiated in Aug. 1997 using 50 rooted liners of Syngonium podophyllum 'White Butterfly' from tissue culture planted into $15-\mathrm{cm}(1.6 \mathrm{~L})$ pots filled with Vergro Container Mix A (2 Canadian peat : 1 perlite : 1 vermiculite; Verlite Co., Tampa, Fla.). Plants were grown in a shaded greenhouse with a maximum photosynthetic photon flux $(P P F)$ of $250 \mu \mathrm{mol} \cdot \mathrm{m}^{-2} \cdot \mathrm{s}^{-1}$ under natural photoperiod with high/low temperature set points of $35 / 18^{\circ} \pm 2{ }^{\circ} \mathrm{C}$. Length and
Table 1. Effect of a single foliar spray of gibberellic acid $\left(\mathrm{GA}_{3}\right)$, applied during August, on plant growth and flowering of Syngonium podophyllum 'White Butterfly' grown in 15-cm pots. Means are averages for 10 plants per treatment.

\begin{tabular}{lccccccc}
\hline $\begin{array}{l}\text { Treatment } \\
\text { rate } \\
\left(\mathrm{mg} \cdot \mathrm{L}^{-1}\right)\end{array}$ & $\begin{array}{r}\text { Leaf } \\
\text { width } \\
(\mathrm{cm})\end{array}$ & $\begin{array}{c}\text { Leaf } \\
\text { length } \\
(\mathrm{cm})\end{array}$ & $\begin{array}{c}\text { Canopy } \\
\text { height } \\
(\mathrm{cm})\end{array}$ & $\begin{array}{c}\text { No. } \\
\text { vines }\end{array}$ & $\begin{array}{r}\text { Total no. } \\
\text { flowers }\end{array}$ & $\begin{array}{r}\text { Mean no. } \\
\text { flowers/vine }\end{array}$ & $\begin{array}{c}\text { Mean no. } \\
\text { days to flower }\end{array}$ \\
\hline 0 & 10.4 & 19.3 & 27.7 & 0 & 0 & 0.0 & --- \\
250 & 10.5 & 17.4 & 26.6 & 2.6 & 4.8 & 1.8 & 86.0 \\
500 & 10.2 & 17.5 & 26.8 & 4.0 & 7.6 & 1.9 & 86.0 \\
1000 & 10.2 & 17.0 & 26.4 & 4.4 & 8.7 & 2.0 & 85.6 \\
2000 & 10.8 & 18.7 & 28.2 & 4.9 & 11.3 & 2.4 & 83.3 \\
Significance & NS & $\mathrm{L}^{*}$ & NS & $\mathrm{L}^{* *}, \mathrm{Q}^{* *}$ & $\mathrm{~L}^{* *}, \mathrm{Q}^{* *}$ & $\mathrm{~L}^{* *}, \mathrm{Q}^{* *}$ & NS
\end{tabular}

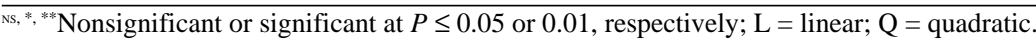

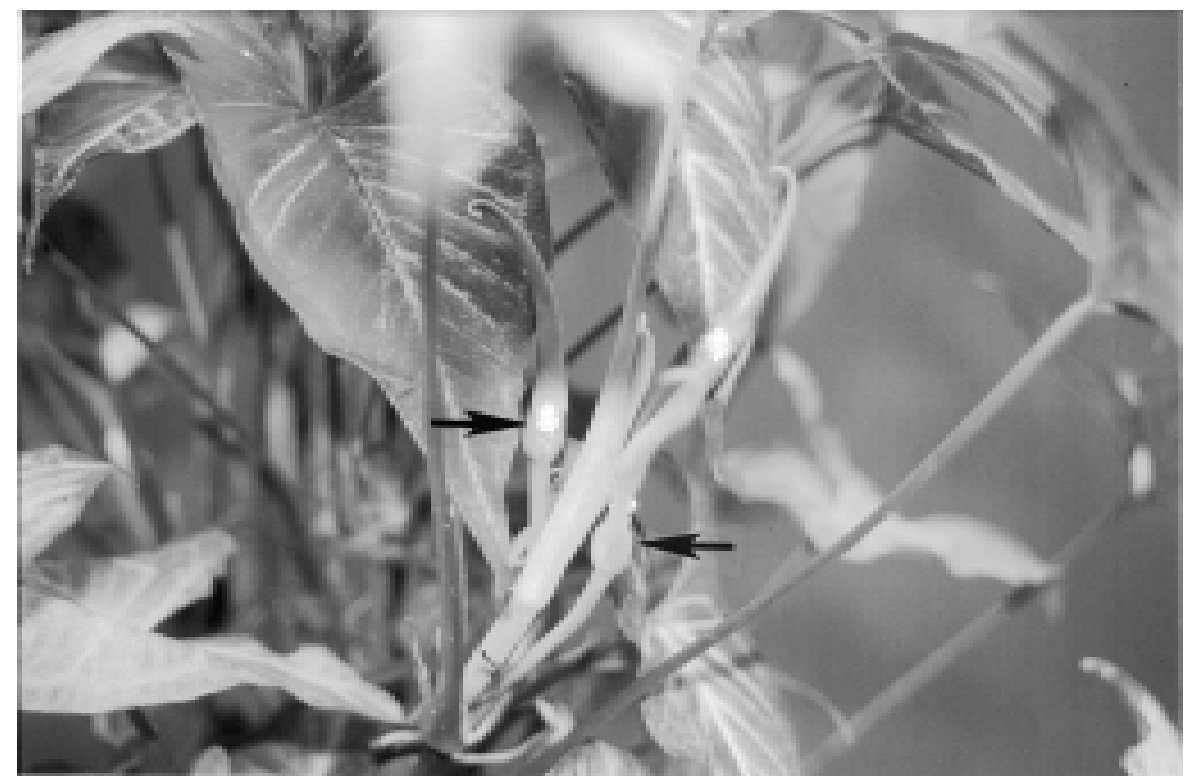

Fig 1. A flowering plant of Syngonium podophyllum 'White Butterfly' $90 \mathrm{~d}$ after treatment with a single foliar spray of $\mathrm{GA}_{3}$ at $1000 \mathrm{mg} \cdot \mathrm{L}^{-1}$. Arrows indicate the flowers. 
width of the largest leaf, and canopy height were measured the day before treatment. Levels of $\mathrm{GA}_{3}$ (GibGro 4\% $\mathrm{GA}_{3}$ liquid; Agtrol Chemical Products, Houston, Texas) tested ranged from 250 to $2000 \mathrm{mg} \cdot \mathrm{L}^{-1}$ a.i. Two hundred milliliters of each treatment solution, with two drops of Tween 20 added as wetting agent, was sprayed as evenly as possible among 10 replicates. Final data included plant canopy height, length and width of the largest leaf, number of vines, total number of flowers, and number of days to the first open flower (indicated by unfurling of the spathe) on each plant.

\section{Results and Discussion}

None of the control plants flowered during the course of this experiment. Ninety percent of plants treated with $250 \mathrm{mg} \cdot \mathrm{L}^{-1} \mathrm{GA}_{3}$ flowered, while all flowered at the higher rates. The total number of flowers per plant and the mean number of flowers per vine both increased significantly linearly and quadratically with rate (Table 1). Flowers were normal in appearance and were fertile (Fig. 1)

Treatment with $\mathrm{GA}_{3}$ had no significant effect on leaf width or canopy height; leaf length was slightly (although significantly) shorter than that of the controls at all $\mathrm{GA}_{3}$ levels. However, $\mathrm{GA}_{3}$ had an effect on apical dominance at higher concentrations, as there was a significant linear and quadratic increase in the number of vines per plant. In a previous report (Imamura and Higaki, 1988), GA 3 applied to Anthurium andraeanum Linden. induced an increase in new shoot number in plants that had been topped, but not in intact plants. In a separate report, $\mathrm{GA}_{3}$ treatment of Anthurium scherzeranum Schott. to induce flowering caused no increase in branching (Henny and Hamilton, 1992). Other aroid genera have not produced additional secondary branches following $\mathrm{GA}_{3}$ treatment (Henny, 1980, 1981, 1983).

Treatment with $\mathrm{GA}_{3}$ had no significant effect on flowering time; all flowering plants produced the first open spathe $\approx 85 \mathrm{~d}$ following treatment. In a second experiment, winter treatment of Syngonium induced flowering within $\approx 120 \mathrm{~d}$ (data not shown). The delay in flowering can be explained by slower plant growth due to cooler greenhouse temperatures.
This study indicates that $\mathrm{GA}_{3}$ can increase the number of vines and mean number of flowers per vine in Syngonium. The increased flower number should help plant breeders provide a more diverse selection of cultivars.

\section{Literature Cited}

Henley R.W. and C.A. Robinson. 1993. Nephthytis cultivars to know and grow. Proc. Fla. State Hort. Soc. 106:343-347.

Henny, R.J. 1980. Gibberellic acid $\left(\mathrm{GA}_{3}\right)$ induces flowering in Dieffenbachia maculata 'Perfection'. HortScience 15:613.

Henny, R.J. 1981. Promotion of flowering in Spathiphyllum 'Mauna Loa' with gibberellic acid. HortScience 16:554-555.

Henny, R.J. 1983. Flowering of Aglaonema commutatum 'Treubii' following treatment with gibberellic acid. HortScience 18:374.

Henny, R.J. and R.L. Hamilton. 1992. Flowering of anthurium following treatment with gibberellic acid. HortScience 27:1328.

Imamura, J.S. and T. Higaki. 1988. Effect of $\mathrm{GA}_{3}$ and BA on lateral shoot production on anthurium. HortScience 23:353-354.

Sheehan, P. 1994. Foliage facts. Florida Dept. Agr. \& Consumer Serv. 